\title{
Passability of Chironomid Larvae in Granular Activated Carbon
}

\author{
Cha Young Lee ${ }^{1}\left(\mathbb{D}\right.$, Jinseok Byeon ${ }^{2}$, Min Kyung Kim ${ }^{1,3}$, Tae-gwan Lee ${ }^{4}$ and Dong Gun Kim ${ }^{1,5, *(\mathbb{D})}$ \\ 1 Institute of Environmental Ecology, Sahmyook University, Seoul 01795, Korea; sincea@naver.com (C.Y.L.); \\ min4190@naver.com (M.K.K.) \\ 2 Department of Chemistry \& Life Science, Sahmyook University, Seoul 01795, Korea; a213079@naver.com \\ 3 Department of Bio \& Environment Technology, Seoul Women's University, Seoul 01797, Korea \\ 4 Department of Environmental Science, Keimyung University, Daegu 42403, Korea; wateree@kmu.ac.kr \\ 5 Smith College of Liberal Arts, Sahmyook University, Seoul 01795, Korea \\ * Correspondence: ecology@syu.ac.kr; Tel.: +82-2-3399-1919
}

Citation: Lee, C.Y.; Byeon, J.; Kim, M.K.; Lee, T.-g.; Kim, D.G. Passability of Chironomid Larvae in Granular Activated Carbon. Int. J. Environ. Res. Public Health 2022, 19, 1005. https:// doi.org/10.3390/ijerph19021005

Academic Editors: Soon-Jin Hwang, Young-Seuk Park, Ihn-Sil Kwak and Dino Musmarra

Received: 22 November 2021

Accepted: 14 January 2022

Published: 17 January 2022

Publisher's Note: MDPI stays neutral with regard to jurisdictional claims in published maps and institutional affiliations.

Copyright: (C) 2022 by the authors. Licensee MDPI, Basel, Switzerland. This article is an open access article distributed under the terms and conditions of the Creative Commons Attribution (CC BY) license (https:// creativecommons.org/licenses/by/ $4.0 /)$.

\begin{abstract}
We conducted an experiment to confirm the passability of chironomid larvae (Glyptotendipes tokunagai) in granular activated carbon (GAC) used in water treatment plants. After injecting larvae at different growth stages (first through fourth instars) into circular columns filled with GAC, the number of individuals and their locations within the GAC columns were recorded after $168 \mathrm{~h}$. We found that more than $80 \%$ of the injected larvae in the first instar and $3.3 \%$ in the second instar passed, whereas none from the third and fourth instars had passed through the column. The second instar larvae were evenly distributed within the column, whereas the third and fourth instar larvae were mostly distributed within $10 \mathrm{~cm}$ of the upper layer of the GAC. Our results demonstrate the passability of chironomid larvae in GAC and can be used as basic information for water quality management in water treatment plants.
\end{abstract}

Keywords: Glyptotendipes tokunagai; granular activated carbon; passability; filtration; backwashing

\section{Introduction}

Supplying high-quality drinking water is very important for human welfare. Supply standards of drinking water include the absence of pathogenic microorganisms, inorganic and organic substances that have a detrimental effect on health, substances that affect the aesthetics of drinking water, and other substances that can have harmful effects on human health [1]. These contaminants are present in rivers, lakes, groundwater, and reservoirs used as drinking water resources [2]. To remove these contaminants, water from a reservoir is usually purified through coagulation with chemical additions, sedimentation, and filtration. There are many different types of materials used in filters, and granular activated carbon (GAC), which has a high adsorption capacity for these substances, is widely used to remove them in the filtration processes of water treatment plants $[3,4]$.

In Korea, the first reported occurrence of macroinvertebrates in domestic tap water supplied from water treatment plants occurred in Incheon in July 2020. Macroinvertebrates were identified as chironomid larvae, and as a result of a nation-wide inspection of water treatment plants, larvae were detected at 7 of 49 sites [5]. The family Chironomidae is the most dominant and cosmopolitan family in the order Diptera [6]. Because chironomid larvae are resistant to pollution, they have been used as test species for the risk assessment of various contaminants [7]. The larvae found in the water treatment plants in the Incheon area were identified as Chironomus kiiensis, Chironomus flaviplumus, Chironomus dorsalis, and Polypedilum yongsanensis [8]. If the infiltration route of chironomid adults into water treatment plants is not completely blocked, it is possible that these insects may multiply.

The assessment of drinking water quality is accomplished based on physicochemical criteria. The problems associated with occurrence of invertebrates in drinking water have received increasing attention in recent years. The occurrence of visible invertebrates in tap 
water causes psychological discomfort to consumers and decreases consumer confidence in tap water quality [8-16]. In addition, it can lead to indirect negative effects such as microbial regrowth $[11,12]$. In the case of benthic macroinvertebrates, most of these are eliminated during the filtration of the surface water, but it has been reported that some remain in the GAC or biological activated carbon (BAC) filter layer and can survive. The presence of living macroinvertebrates in filters in water treatment plants has been reported worldwide. Copepoda, Rotatoria, and Diptera are the most common taxa in water treatment plants $[9,12,13,16-18]$. However, most previous studies have confirmed the presence of invertebrates in filters, and few studies have been conducted on the possibility of physical filtration of larvae in water treatment plants, along with their ecological aspects. By identifying that possibility, we can determine whether current water quality standards are adequate or any further steps may be required.

The objective of this study was to assess the passability of chironomid larvae in GAC using Glyptotendipes tokunagai, one of the most dominant species in urban streams in Korea, at the laboratory scale. We tested the passability of larvae in the GAC at larval instar stages and interpreted the results ecologically. In addition, the time required for larvae to pass through the GAC column was verified.

\section{Materials and Methods}

\subsection{Experimental Species}

The species used in this experiment, G. tokunagai, is distributed throughout East Asia and was first recorded in Korea in 1981 [7,19]. They are one of the dominant species in urban streams because of their pollutant tolerance, and they are used for various laboratory experiments because they are easy to rear indoors [7,20-22]. G. tokunagai has four larval stages [7]; accordingly, in this experiment, the passability of larvae in the GAC was tested for each larval stage. The larvae used in our experiment were supplied by the laboratory at Division of Environmental Science and Ecological Engineering, Korea University (Seoul, Korea), where G. tokunagai was reared indoors. Egg masses were oviposited at almost the same time, reared at a constant temperature (approximately $25^{\circ} \mathrm{C}$ ) in the laboratory, and each time the larvae hatched or molted at each stage, they were used in the experiment as soon as possible. Before the injection of larvae, we confirmed the head width of larvae using stereo microscope (SZ61, Olympus, Tokyo, Japan) to double check the instar stages [23].

\subsection{Experimental Procedures}

To test the passability of G. tokunagai larvae in GAC used in water treatment plants, acrylic circular columns filled with GAC were used in the experiment (Figure 1a). The standard size of the columns was $300 \mathrm{~mm}$ in height and $27.5 \mathrm{~mm}$ in diameter. In each column, $1 \mathrm{~cm}$ of sand (particles approximately $2 \mathrm{~mm}$ in diameter) was laid on the bottom, and $23 \mathrm{~cm}$ of GAC (Kaya Activated Carbon Inc., Seoul, Korea) was placed at the top. The ranges of particle size and uniformity coefficient (UC) of GAC in Criteria for Waterworks Facilities [4] are 0.4-2.4 mm and 1.3-2.1, respectively. According to these criteria, the ranges of particle size and UC of GAC used in this experiment were $0.6-2.3 \mathrm{~mm}$ and 1.7, respectively. Thirty G. tokunagai individuals within the same larval stage were injected, and this step was repeated for each of the four larval stages without food resources. Because the standard filtration speed of the rapid filter system was $120-150 \mathrm{~m} \cdot \mathrm{d}^{-1}$ [4], the filtration speed in each column was maintained at approximately $150 \mathrm{~m} \cdot \mathrm{d}^{-1}$ (flow rate $63 \mathrm{~mL} \cdot \mathrm{min}^{-1}$ ) with the use of a submersible pump (UP 500, Hyubshin Water Design, Seoul, Korea) according to the standard. The linear velocity was $6.4 \mathrm{~m} \cdot \mathrm{h}^{-1}$, which met the criteria for waterworks facilities $\left(2-34 \mathrm{~m} \cdot \mathrm{h}^{-1}\right)$ [4]. Tap water was used for the experiment, and the average turbidity, residual chlorine, $\mathrm{pH}$, and temperature of the water were $0.03 \mathrm{NTU}$, $0.94 \mathrm{mg} \cdot \mathrm{L}^{-1}, 7.09$, and $25.2^{\circ} \mathrm{C}$, respectively. The larvae were screened from the water filtered by the GAC using a $45-\mu \mathrm{m}$ sieve (ChungGye Sieve, Seoul, Korea) (Figure 1b). Because the recorded minimum head width of the first instar larvae was approximately $0.04 \mathrm{~mm}$ [23], the first and second instar larvae were double-screened by adding a $25-\mu \mathrm{m}$ 
sieve. The number of passing individuals was recorded every $8 \mathrm{~h}$ after the larvae were injected. At each confirmation, a new sieve was placed on the outlet tube, and the larvae were visually confirmed using a stereo microscope (SZ61, Olympus, Tokyo, Japan) as they were in the filtered sieve for $8 \mathrm{~h}$. The experiment was conducted for $168 \mathrm{~h}$, because the average backwashing cycle in domestic water treatment plants was $7 \mathrm{~d}$. The average development time of G. tokunagai larvae stages with sufficient food supply is approximately $147 \mathrm{~h}\left(\right.$ at $\left.25^{\circ} \mathrm{C}\right)$, and since the development period of chironomid becomes longer under resource-limited conditions, we assumed that there was no change in the larval stage at 168 $h$ of experiment $[7,24]$. To determine the location of the larvae remaining in the GAC layer after $168 \mathrm{~h}$, the GAC was poured into a white tray (1426B Larval tray, BioQuip, Rancho Dominguez, CA, USA), and the number of larvae was counted for every 3-cm section of the GAC material.
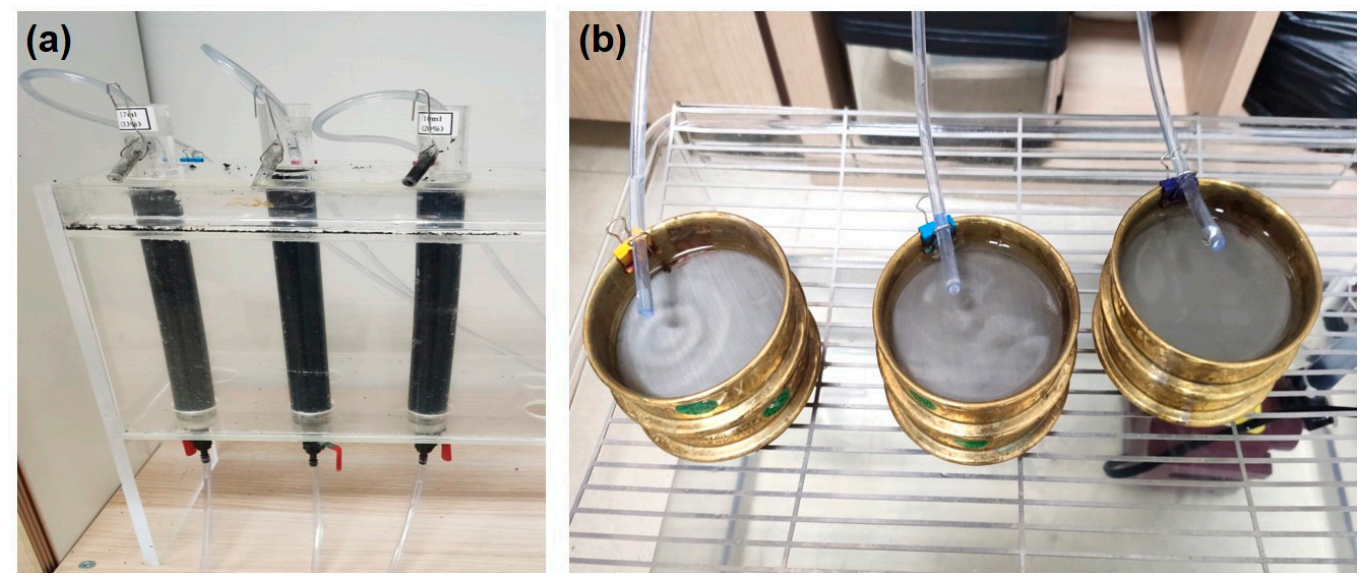

Figure 1. The columns filled with granular activated carbon (GAC) used in the experiments (a). Larvae that passed through GAC column were confirmed by filtering using sieves (b).

\subsection{Data Analysis}

The recommended $t$-test for small sample sizes [25] was used to compare the density of G. tokunagai larvae in the GAC columns according to the instar. The Kruskal-Wallis test, followed by Bonferroni's multiple comparisons, was used to test for differences in larval densities according to depth. The Jonckheere-Terpstra test was used to determine the depth dependency. All statistical analyses were performed using SPSS version 25.0 at a significance level of 0.05 .

\section{Results and Discussion}

With respect to the passability of larvae in the GAC according to larval stage, only first and second instar larvae passed through the GAC, and the pass rate of first instar larvae was higher than that of second instar larvae ( $t$-test, $p=0.01)$. First instar larvae were first detected $48 \mathrm{~h}$ after being injected into the GAC column, and more than $80 \%$ of the injected larvae passed after $72 \mathrm{~h}$. In the case of the second instar larvae, passing individuals were first confirmed $72 \mathrm{~h}$ after injection. There were no passing individuals in the third and fourth instars (Figure 2). Because backwashing of GAC has a great effect on water quality in water treatment plants, backwashing conditions and cycles are very important factors to consider for efficient water quality management [26]. The backwashing cycle of activated carbon filters in domestic water treatment plants occur once every 3-5 days during the summer season [27]. According to our experimental results, the backwashing cycle may need to be adjusted to less than $48 \mathrm{~h}$ to prevent the chironomid larvae from spreading to the drinking water distribution system during the activity period of chironomids. Optimization of the backwashing procedure is known to be efficient in the removal of invertebrates [18], and our results can be helpful in determining the backwashing cycle of water treatment plants. 


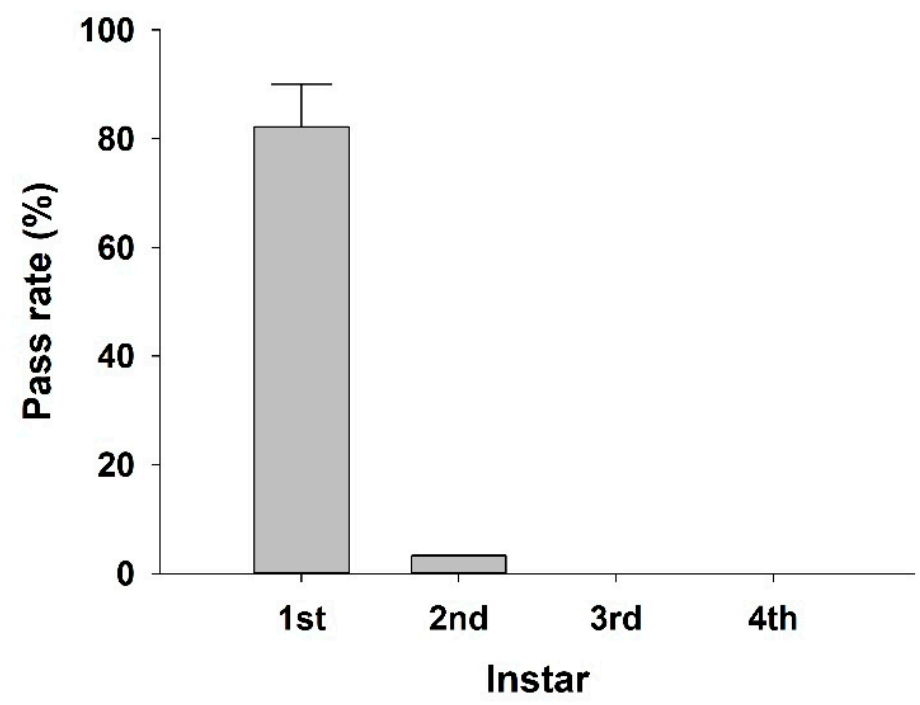

Figure 2. Pass rate of the four instars of Glyptotendipes tokunagai larvae through a granular activated carbon (GAC) column.

At the end of the experimental period $(168 \mathrm{~h})$, we confirmed the location of the larvae in the GAC columns in $3 \mathrm{~cm}$ sections. The first instar larvae were excluded from this test because more than $80 \%$ of the injected individuals passed through the GAC. The percentage of larvae injected to passing larvae was $63.3 \%$ in the second instar, $65.6 \%$ in the third instar, and $44.4 \%$ in the fourth instar. The loss of larvae was believed to be due to cannibalism resulting from a lack of food in the experimental environment [28]. Organisms generally require more energy as they grow; therefore, fourth instar larvae may have higher energy requirements than larvae at earlier stages, resulting in more cannibalism in the fourth instar.

Second instar larvae were evenly distributed throughout GAC (Figure 3a). At the 0-3 cm section, the densities of third and fourth instar larvae decreased significantly with increasing depth of GAC (Jonckheere-Terpstra; Figure 3 and Table 1). Among the confirmed third instar larvae, $86.4 \%$ were present at a depth of $3 \mathrm{~cm}$ from the inlet, and $94.9 \%$ were present at a depth of $9 \mathrm{~cm}$ (Figure $3 \mathrm{~b}$ ). In the case of confirmed fourth instar larvae, they were mostly found below the inlet, with $95.0 \%$ distribution within $3 \mathrm{~cm}$ (Figure 3c). Oliver [29] reported that approximately 95\% of chironomid larvae usually burrow within the upper $10 \mathrm{~cm}$ of the substrate, and our results also reflected this larval habit. Larvae construct tubes composed of endogenously produced silk and substrate materials [30,31], and the third and fourth instar larvae seem to have built a tube and withstood the flow of water rather than passing through the GAC. Newly hatched benthic macroinvertebrates use flowing water to disperse from hatching sites to appropriated habitats, and chironomid larvae also float and remain in a planktonic state until they find a suitable habitat $[29,32]$. This is likely the reason why over $80 \%$ of the first instar larvae passed through the experimental GAC in our study.

Table 1. Results of Kruskal-Wallis and Jonckheere-Terpsta tests determining whether significant differences exist between the abundance of larvae at different depths in the granular activated carbon (GAC) column.

\begin{tabular}{ccc}
\hline Instar & Kruskal-Wallis & Jonckheere-Terpstra \\
\hline Second & NS $^{1}$ & NS \\
\hline Third & NS & 0.009 \\
\hline Fourth & 0.05 & 0.034 \\
\hline
\end{tabular}

${ }^{1} \mathrm{NS}=$ not significant. 


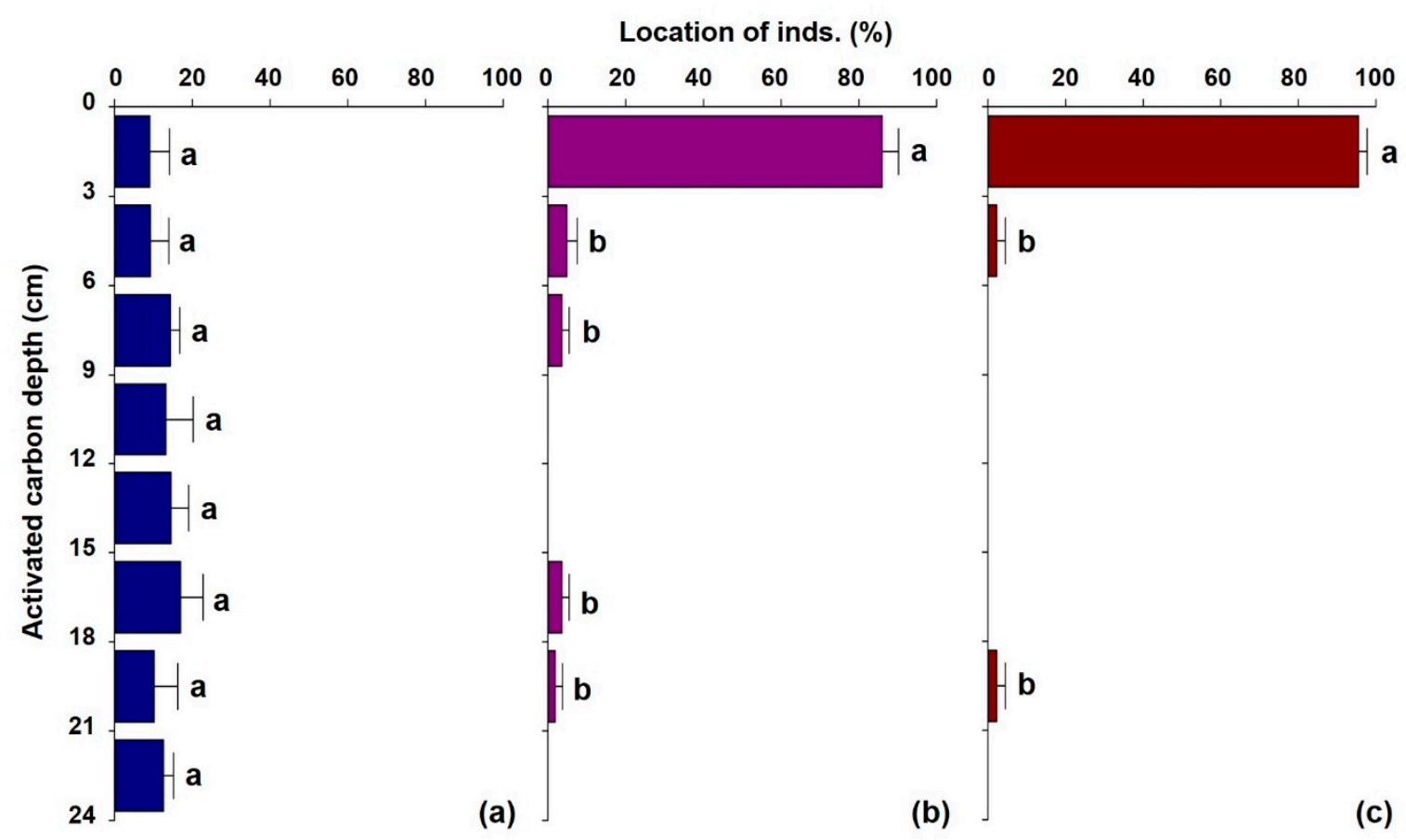

Figure 3. Distribution ratio of Glyptotendipes tokunagai larvae detected in 3-cm sections of GAC after $168 \mathrm{~h}$ of passage by larvae in the second instar (a), third instar (b), and fourth instar (c). Different letters indicate statistically significant differences at the 0.05 level in the Jonckheere-Terpstra test.

When macroinvertebrates can be seen in domestic tap water, their aesthetic impact on perceived water quality is enormous, even if the frequency of such occurrences is low. In studies of benthic macroinvertebrates in drinking water systems in Europe, not only chironomid larvae, but also various macroinvertebrates such as water louse (Asellus aquaticus), cave water louse (Proasellus cavaticus), and detritus worms (Oligochaeta spp.) were found $[11,33]$. However, in these studies, samples were collected from water reservoirs or pipes in drinking water supply networks $[11,14,34]$. In the current study, we confirmed the possibility of macroinvertebrates physically filtered from the GAC used in a water treatment facility, which is a stage before pipe inflow. If chironomid larvae pass through GAC, they may enter the drinking water networks, where they might reproduce within the pipes and eventually enter the home water supply. A few species of Chironomidae, such as Limnophyes asquamatus and Paratanytarsus grimmii, which are widely distributed in North America, Australia, and Europe, can multiply parthenogenetically without reaching the adult stage [11,35]. Egg masses of Chironomidae have been found to serve as a reservoir for Vibrio cholera and Aeromonas spp., and Chironomidae may cause the spread of pathogenic bacteria into drinking water networks [36].

Maintaining good water quality requires various efforts, such as the management of water treatment processes (including regular pipe flushing and backwashing cycles) and monitoring the occurrence of macroinvertebrates. Our experiment confirmed the passability of chironomid larvae in GAC at different instars, and can provide guidelines for estimating water treatment standards. The first instar larvae passed through the GAC after $48 \mathrm{~h}$, and this could be evidence suggesting that the backwashing cycle of water treatment plants should be controlled to within $2 \mathrm{~d}$. Moreover, it is expected to provide basic data for improved experiments such as the testing of GAC filtering efficiency with different variables or the development of a GAC sorption model.

\section{Conclusions}

The supply of clean water is often taken for granted; thus, the detection of chironomid larvae in tap water is a cause of anxiety for the general public. In response to civil com- 
plaints, the Korean government has proposed management plans to provide high-quality water. With this goal in mind, we conducted experiments on the physical passability of chironomid larvae in GAC used in water treatment plants, and the results were interpreted in relation to the ecological characteristics of Chironomidae. Our experimental results demonstrated the potential for chironomid larvae to be transmitted into drinking water networks using the current management method, and the data can be used as a reference for establishing guidelines for the management of water treatment plants. Currently, the backwashing cycle of activated carbon in domestic water treatment plants is three to five days in summer, but we propose to adjust the cycle to less than $48 \mathrm{~h}$ during the activity period of the chironomid. Improved studies are needed to relieve consumers' anxiety about the occurrence of invertebrates in tap water, and our study can be used as basic data for those studies.

Author Contributions: C.Y.L. analyzed the research data and wrote the manuscript. J.B. and M.K.K. conducted the experiments and supported the writing of the manuscript. T.-g.L. revised the manuscript. D.G.K. supervised and served as mentor for the overall study. All authors have read and agreed to the published version of the manuscript.

Funding: This research received no external funding.

Institutional Review Board Statement: Not applicable.

Informed Consent Statement: Not applicable.

Data Availability Statement: The data presented in this study are available on request from the corresponding author.

Conflicts of Interest: The authors declare that they have no conflict of interest.

\section{References}

1. Ministry of Environment (MOE). Drinking Water Management Act. Available online: https://www.law.go.kr/LSW/lsInfoP.do? efYd=20210401\&lsiSeq=216343\#0000 (accessed on 1 October 2021).

2. Nishijima, W.; Speitel, G.E., Jr. Fate of biodegradable dissolved organic carbon produced by ozonation on biological activated Carbon. Chemosphere 2004, 56, 113-119. [CrossRef]

3. Yapsakli, K.; Çeçen, F. Effect of type of granular activated carbon on DOC biodegradation in biological activated carbon filters. Process Biochem. 2010, 45, 355-362. [CrossRef]

4. Ministry of Environment (MOE). Criteria for Waterworks Facilities (2010) (In Korean). Available online: http:/ / www.me.go.kr/ home/web/policy_data/read.do? menuId=10264\&seq=4769 (accessed on 31 December 2021).

5. National Assembly Research Service. Occurrence of Larvae in Tap Water and Improvement Tasks. Available online: https: //www.nars.go.kr/index.do (accessed on 18 October 2021).

6. Ashe, P.; Murray, D.A.; Reiss, F. The zoogeographical distribution of Chironomidae (Insecta: Diptera). Ann. Limnol. -Int. J. Lim. 1987, 23, 27-60. [CrossRef]

7. Baek, M.J.; Yoon, T.J.; Bae, Y.J. Development of Glyptotendipes tokunagai (Diptera: Chironomidae) under different temperature conditions. Environ. Entomol. 2012, 41, 950-958. [CrossRef]

8. Kwak, I.-S.; Park, J.-W.; Kim, W.-S.; Park, K. Morphological and genetic species identification in the Chironomus larvae (Diptera: Chironomidae) found in domestic tap water purification plants. Korean J. Ecol. Environ. 2020, 53, 286-294. [CrossRef]

9. Wu, Z.; Tang, X.; Chen, H. Seasonal and treatment-process variations in invertebrates in drinking water treatment plants. Front. Environ. Sci. Eng. 2021, 15, 62. [CrossRef]

10. van Lieverloo, J.H.M.; Bosboom, D.W.; Bakker, G.L.; Brouwer, A.J.; Voogt, R.; De Roos, J.E.M. Sampling and quantifying invertebrates from drinking water distribution mains. Water Res. 2004, 38, 1101-1112. [CrossRef] [PubMed]

11. Gunkel, G.; Michels, U.; Scheideler, M. Water lice and other macroinvertebrates in drinking water pipes: Diversity, abundance and health risk. Water 2021, 13, 276. [CrossRef]

12. $\mathrm{Wu}, \mathrm{Z}$.; Chen, H. Comparison of invertebrate removal by traditional-BAC and pre-BAC treatment processes: Verification in a full-scale drinking water treatment plant. Water Supply 2018, 18, 1261-1269. [CrossRef]

13. Wotton, R.S.; Hirabayashi, K. Midge larvae (Diptera: Chironomidae) as engineers in slow sand filter beds. Water Res. 1999, 33, 1509-1515. [CrossRef]

14. Alexander, M.K.; Merritt, R.W.; Berg, M.B. New strategies for the control of the parthenogenetic chironomid (Paratanytarsus grimmii) infecting water systems. J. Am. Mosq. Control Assoc. 1997, 13, 189-192. 
15. Christensen, S.C.B.; Nissen, E.; Arvin, E.; Albrechtsen, H.J. Distribution of Asellus aquaticus and microinvertebrates in a nonchlorinated drinking water supply system - effects of pipe material and sedimentation. Water Res. 2011, 45, 3215-3224. [CrossRef] [PubMed]

16. Dong, Z.; Yin, W.; Yang, J.; Zhang, J.; Jiang, C. Risk assessment and inactivation of invertebrate-internalized bacteria in pilot-scale biological activated carbon filtration. Sci. Total Environ. 2019, 676, 321-332. [CrossRef]

17. Weeks, M.A.; Leadbeater, B.S.C.; Callow, M.E.; Bale, J.S.; Barrie Holden, J. Effects of backwashing on the prosobranch Snail Potamopyrgus Jenkinsi Smith in granular activated carbon (GAC) adsorbers. Water Res. 2007, 41, 2690-2696. [CrossRef] [PubMed]

18. Schreiber, H.; Schoenen, D.; Traunspurger, W. Invertebrate colonization of granular activated carbon filters. Water Res. 1997, 31, 743-748. [CrossRef]

19. Na, K.B. Taxonomy of the Chironmidae (Diptera, Insecta) in Seoul-Gyeonggi Area, Korea. Master's Thesis, Seoul Women's University, Seoul, Korea, 2004.

20. Choi, S.; Kim, S.; Bae, Y.-J.; Park, J.-W.; Jung, J. Size-dependent toxicity of silver nanoparticles to Glyptotendipes tokunagai. Environ. Health Toxicol. 2015, 30, e2015003. [CrossRef] [PubMed]

21. Baek, M.J.; Yoon, T.J.; Kim, D.G.; Lee, C.Y.; Cho, K.; Bae, Y.J. Effects of road deicer runoff on benthic macroinvertebrate communities in Korean freshwaters with toxicity tests of Calcium chloride $\left(\mathrm{CaCl}_{2}\right)$. Water Air Soil Pollut. 2014, 225, 1961. [CrossRef]

22. Baek, M.J.; Yoon, T.J.; Kang, H.J.; Bae, Y.J. Biological and genetic characteristics of Glyptotendipes tokunagai (Diptera: Chironomidae) on the basis of successive rearing of forty-two generations over seven years under laboratory conditions. Environ. Entomol. 2014, 43, 1406-1418. [CrossRef]

23. Baek, M.J. Temperature-dependent development and successive rearing of Glyptotendipse tokunagai (Dipera: Chironomidae). Master's Thesis, Seoul Women's University, Seoul, Korea, 2009.

24. Hooper, H.L.; Sibly, R.M.; Hutchinson, T.H.; Maund, S.J. The influence of larval density, food availability and habitat longevity on the life history and population growth rate of the midge Chironomus riparius. Oikos 2003, 102, 515-524. [CrossRef]

25. de Winter, J.C.F. Using the Student's t-test with extremely small sample sizes. Pract. Assess. Res. Eval. 2013, 18, 10. [CrossRef]

26. Ahmad, R.; Amirtharajah, A.; Al-Shawwa, A.; Huck, P.M. Effects of backwashing on biological filters. J. Am. Water Works Assoc. 1998, 90, 62-73. [CrossRef]

27. Kim, S.-G.; Park, H.-G.; Son, H.-J.; Yoom, H.-S.; Ryu, D.-C. Evaluation of influence factors for determination of proper backwashing time of biological activated carbon (BAC) process in drinking water treatment process. J. Environ. Sci. Int. 2015, 24, 1551-1558. [CrossRef]

28. Niedrist, G.H.; Füreder, L. Trophic ecology of alpine stream invertebrates: Current status and future research needs. Freshw. Sci. 2017, 36, 466-478. [CrossRef]

29. Oliver, D.R. Life history of the Chironomidae. Annu. Rev. Entomol. 1971, 16, 211-230. [CrossRef]

30. Mckie, B.G. Disturbance and investment: Developmental responses of tropical lotic midges to repeated tube destruction in the juvenile stages. Ecol. Entomol. 2004, 29, 457-466. [CrossRef]

31. Hershey, A.E. Tubes and foraging behavior in larval Chironomidae: Implications for predator avoidance. Oecologia 1987, 73, 236-241. [CrossRef]

32. Begon, M.; Townsend, C.R.; Harper, J.L. Ecology: From Individuals to Ecosystem, 4th ed.; Wiley-Blackwell: Oxford, UK, 2006; pp. 132-185.

33. van Lieverloo, J.H.M.; Hoogenboezem, W.; Veenendaal, G.; van der Kooij, D. Variability of invertebrate abundance in drinking water distribution systems in the Netherlands in relation to biostability and sediment volumes. Water Res. 2012, 46, 4918-4932 [CrossRef]

34. Evins, C. Small animals in drinking-water distribution systems. In Safe Piped Water: Managing Microbial Water Quality in Piped Distribution Systems; Ainsworth, R., Ed.; World Health Organization. IWA Publishing: London, UK, 2004; pp. 101-120. ISBN 1843390396.

35. Dettinger-Klemm, P.M.A. Chironomids (Diptera, Nematocera) of Temporary Pools-An Ecological Case Study. Ph.D. Thesis, Philipps-Universität Marburg, Marburg, Germany, 2003.

36. Figueras, M.J.; Beaz-Hidalgo, R.; Senderovich, Y.; Laviad, S.; Halpern, M. Re-identification of Aeromonas isolates from chironomid egg masses as the potential pathogenic bacteria Aeromonas aquariorum. Environ. Microbiol. Rep. 2011, 3, 239-244. [CrossRef] 